\title{
23. REMAINS OF EARLY CRETACEOUS AMMONITES AND OF A FISH FROM DEEP SEA DRILLING PROJECT SITE 6031
}

\author{
P. J. Hoedemaeker, Rijksmuseum van Geologie en Mineralogie, Leiden²
}

\section{INTRODUCTION}

Shipboard examination of the interbedded laminated marls, bioturbated limestones, and sandstone to claystone turbidites of Lower Cretaceous lithologic Unit V at Site 603 revealed the presence of ammonites and aptychi. An entire ammonite was found on the upper surface of a whole-core interstitial water sample (see frontispiece). The ammonites and the aptychus were examined in an attempt to determine their taxonomy and age. Unfortunately, the ammonites found in Hole 603B consist of poorly preserved fragments of long-ranging forms that can only be tentatively identified. These ammonite remains do not merit more than a short taxonomic note.

A sample originally identified aboard ship as a section through a double-valved aptychus has subsequently been identified as belonging to a fish. This constitutes the second find of identifiable vertebrate remains in a Deep Sea Drilling Project hole, the first being the fish vertebrae from Leg 41, Section 367-18-2 (Lancelot, Seibold, et al., 1978, frontispiece A).

\section{SYSTEMATIC DESCRIPTIONS Hypophylloceras sp.}

Sample 603B-44-3, 140-150 cm (top of interstitial water sample).

Delicate shell fragments of a flattened specimen of Hypophylloceras (Fig. 1) were found on the upper surface of an interstitial water sample. The other half of the impression of this specimen was found divided between the work and archive halves of the lowermost surface of Section 603B-44-3. Unfortunately, specific identification was impossible. Hypophylloceras has been reported from upper Tithonian through Maestrichtian strata.

Dinoflagellate stratigraphy (Habib and Drugg, this volume) and calcareous nannofossil stratigraphy (Covington and Wise, this volume) indicate that this specimen is of Aptian age.

\section{Lytoceras liebigi (Oppel) in Zittel, 1868, or L. subsequens Karakasch, 1907}

\section{Sample 603B-58-3, 140-150 cm.}

A small fragment of a rounded whorl (Fig. 2A) of a very evolute ammonite was found in this sample. The thin, delicate shell was well preserved and shows a pearly luster. The well-preserved septum (Fig. 2B) identifies the specimen as Lytoceras, with a whorl height equal to the whorl width $(9.3 \mathrm{~mm})$. The ornamentation of the specimen is preserved as fine, slightly convex, prorsiradiate and rather distantly spaced ribs. The rounded whorl section, relatively rapid increase of the whorl height, and the ornamentation are similar to juvenile specimens of $L$. liebigi (Zittel, 1868, pl. 9, fig. 6) and to L. subsequens (Karakasch,

\footnotetext{
${ }^{1}$ van Hinte, J. E., Wise, S. W., Jr., et al., Init. Repts. DSDP, 93: Washington (U.S. Govt, Printing Office).

2 Address: Rijksmuseum van Geologic en Mineralogie, Hooglandse Kerkgracht 17, 2312 HS Leiden, The Netherlands.
}

1907, pl. 5, fig. 9), which are closely related. In adult specimens of these two species, the cross section of the whorls becomes greater in width than in height.

Remarks. Lytoceras subsequens has a slightly wider umbilicus than L. liebigi, but the whorl fragment is too small to be certain about the identification at the specific level. The ribs of $L$. sutile (Oppel) in Zittel, 1868, are more curved. L. anisoptychum Uhlig, 1883, has a more compressed whorl section, whereas the rate at which the whorl height of $L$. subfimbriatum (d'Orbigny, 1840) increases with age is much slower.

Age. Lytoceras liebigi has been reported from upper Tithonian through Barremian strata, $L$. subsequens only from Hauterivian and Barremian. The lower Aptian form of $L$. "liebigi" depicted by Kilian and Reboul (1915, pl. 2, fig. 1) belongs to neither L. liebigi nor $L$. subsequens. Dinoflagellate biostratigraphy (Habib and Drugg, this volume) and calcareous nannofossil biostratigraphy (Covington and Wise, this volume) indicate that the age of this sample is late Hauterivian.

Lytoceras juilleti (d'Orbigny, 1841) or L. vogdti Karakasch, 1907

Sample 603B-69-5, 11 13 cm.

A flattened mold of a very evolute, smooth ammonite of the genus Lytoceras was found in this sample, split along a bedding plane (Fig. 3). Measurements of the specimen are: diameter $2.2 \mathrm{~cm}$, whorl height $0.8 \mathrm{~cm}$, umbilical width $0.8 \mathrm{~cm}$.

Remarks. The measurements of this specimen are reconciliable only with Lytoceras juilleti (d'Orbigny, 1841, pl. 50, figs. 1-3), with $L$. sutile (Oppel) (Zittel, 1868, pl. 12, figs. 1-5), which is interpreted here as being a junior synonym of $L$. juilleti, and with $L$. vogdti (Karakasch, 1907 , pl. 5, fig. 1), which is closely related to L. juilleti. Lytoceras richei Sayn, 1901, has a smaller umbilicus, whereas juvenile forms of $L$. liebigi have a wider umbilicus than this specimen.

Age. Lytoceras juilleti has been reported from upper Tithonian through Barremian strata, $L$. vogdti only from the Barremian. Dinoflagellate biostratigraphy (Habib and Drugg, this volume) and calcareous nannofossil biostratigraphy (Covington and Wise, this volume) indicate that this sample is of early Hauterivian age.

\section{Lamellaptychus beyrichodidayi Trauth, 1938}

Lamellaptychus beyricho-didayi Trauth, 1938, p. 200, pl. 14, fig. 5. Cassinis, 1957, p. 234, pl. 11, fig. 5. Gasiorowski, 1962b, p. 252, fig. 14, no. 27. Gasiorowski, 1962a, p. 106, pl. 7, fig. 6 .

Sample 603B-79-2, 94-95 cm.

This aptychus (Fig. 4) can be readily identified by its coarse, sharp, distant ribs on the outer side, by the absence of chevronlike rib curvature, and by the gradual change of the angle at which the ribs reach the symphysal margin. Younger growth stages have a sharp angle of about $20^{\circ}$ and are reminiscent of Lamellaptychus beyrichi, but in the latest growth stages this angle is rectangular and finally obtuse (approximately $120^{\circ}$ ), reminiscent of L. didayi. The ribs of the latest growth stages curve almost parallel to the outer margin in this species, and this specimen demonstrates a local inflection of the ribs in the depression adjacent to the keel. The inner side of the valves show fine concentric growth lines.

Dimensions. Valve length is $26 \mathrm{~mm}$, valve width is $15 \mathrm{~mm}$, and the width index is 0.58 for this specimen. The length of the symphysal edge could not be measured, but it is smaller than the total length of the valves.

Age. Rare specimens of L. beyrichodidayi have been reported from the Berriasian to lower Valanginian Aptychi Horizon VII of the Car- 


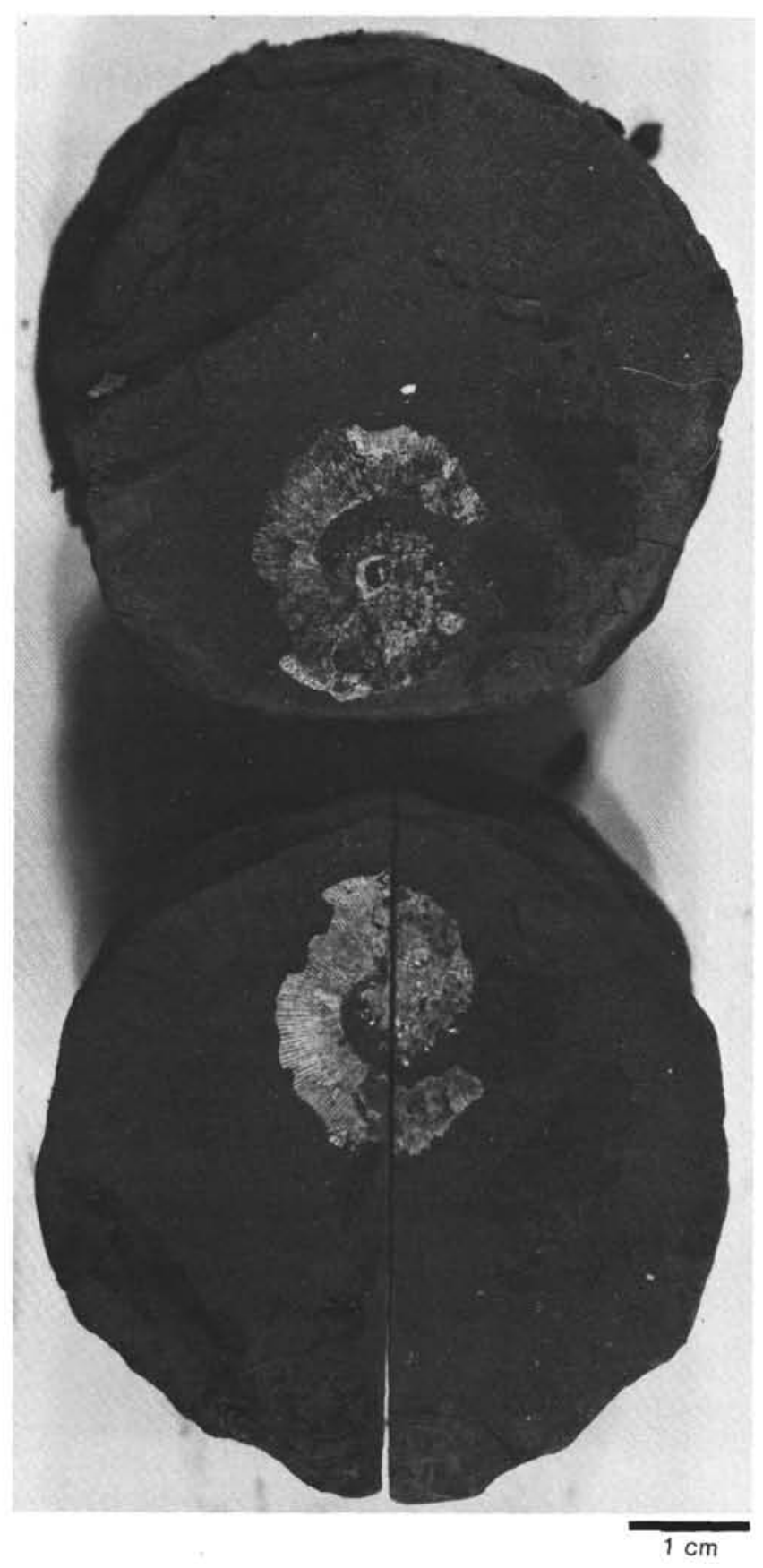

Figure 1. Hypophylloceras sp., $\times 1.5$ (see also frontispiece of this volume). This photograph, taken aboard the ship, shows two sides of the strongly flattened impression of the conch with most of the delicate, pearly, shell fragments still adhering. The specimen reached the laboratory almost entirely without shell fragments. Sample 603B$44-3,140-150 \mathrm{~cm}$.

pathian Mountains of Poland (Gasiorowski, 1962a, p. 79). However, Borza et al. (1980) and Vǎsíček et al. (1983) reported that many specimens of this form were restricted to the upper Valanginian and the lower Hauterivian of ammonite-rich sections in the Carpathian Mountains of Czechoslovakia, which evidently represent the acme of this species.

Dinoflagellate biostratigraphy (Habib and Drugg, this volume) and calcareous nannofossil biostratigraphy (Covington and Wise, this volume) indicate that this sample is early Hauterivian in age.

\section{DISCUSSION}

The Early Cretaceous ammonites found in Hole 603B consist exclusively of Lytoceras and Phylloceras, which are interpreted as being open-ocean dwellers. This generally indicates relatively deep-water deposits. It is doubtful if the L. liebigi/subsequens specimen found in Section 603B-58-3 represents the autochthonous part of the ammonite thanatocoenosis, because abundant allochthonous plant remains are present in the mica-rich clay of this sample. The conch was embedded in nearly vertical position.

All ammonites found in these samples are long-ranging forms not suitable for refined age determination. Lamellaptychus beyrichodidayi had its acme in the late Valanginian to early Hauterivian, but this species occurs sporadically in slightly older sediments.

\section{Fish remains}

Sample 603B-80-1, 23-24 cm.

This sample (Fig. 5) was originally considered by the shipboard scientists of Leg 93 to contain a cross section through two aptychi valves. Subsequent investigation by me and other investigators has indicated that this is the jaw of a small vertebrate, which shows small pointed teeth on two slightly curved dentary fragments. The irregularly sized, cone-shaped teeth are curved backwards. Beside the fragments of the two dentaries, there are two other slender bone fragments on this sample.

The dentary fragments were originally identified by shore laboratory investigation at the Netherlands National Museum of Geology and Mineralogy as being the lower jaw of a small reptile. However, detailed investigation by several specialists indicated that this fossil was probably part of a fish, so the specimen was sent to Dr. C. Patterson of the British Museum of Natural History for identification. Dr. Patterson (personal communication, 1984) indicates that "I have spent a couple of hours looking at the specimen and comparing it with likely fishes. I believe that it is fish, and that it shows the two dentaries (lower jaw) and a couple of indeterminable bones. My problem is that this is all I can say about it: I can determine it only as Actinopterygii. Since that group includes some 20,000 living species and ranges from late Silurian to Recent, in my opinion it does not merit a published note, however short."

Remarks. Despite their fragmentary nature and indeterminate taxonomy, these remains of an actinopterygian fish represent the first vertebrate jaw found in Deep Sea Drilling Project cores.

\section{ACKNOWLEDGMENTS}

I thank the shipboard scientists of Leg 93 for their identification and sampling of the ammonites, Jan van Hinte for arranging the sampling of Site 603 ammonites, and Colin Patterson for examining the fish dentaries. This manuscript has been reviewed by Drs. Peter D. Ward, J. A., Jeletzsky, and Dean A. Dunn.

\section{REFERENCES}

Borza, K., Gašparikova, V., Michalik, J., and Vaš́čck, Z., 1980. Upper Jurassic-Lower Cretaceous sequence of the Križna-nappe (Fatric) in the Strážovcé section, Strážovské Vrchy Mts. (Western Carpathians). Geol. Carpathica, 31 (4):541-562.

Cassinis, G., 1957. Su alcune specie di "Aptychus" del Giura superiore e della Creta inferiore delle Prealpi Bresciane. Riv. Ital. Paleontol. Stratigr., 63 (4):223-246.

Gasiorowski, S. M., 1962a. Aptychi from the Dogger, Malm and Neocomian in the Western Carpathians and their stratigraphical value. Stud. Geol. Pol., 10:1-134.

1962b. Sur les Aptychi à côtes. Ann. Soc. Geol. Pol. (Roczn. Pol. Tow. Geol.), 32 (2):227-280.

Karakasch, N. I., 1907. Le Crétacé inférieur de la Crimée et sa faune. Trav. Soc. Imper. Natur. St.-Petersbourg, 32 (5):1-484.

Kilian, W., and Reboul, P., 1915. Contribution à l'étude des faunes paléocrétacées du Sud-Est de la France. I. La faune de l'Aptien in- 
férieur des environs de Montélimar (Drôme) (Carrière de l'Homme-d'Armes). Mem. Carte Geol. Det. France, pp. 1-221.

Orbigny, A. d', 1840-42. Paléontologie Française: Terrains Crétacés (Vol. 1): Paris (privately published).

Sayn, G., 1901. Les ammonites pyriteuses des marnes valangiennes du Sud-Est de al France. Mem. Soc. Geol. France, Paleontol., 9 (Mem. 23): $1-28$.

Trauth, F., 1938. Die Lamellaptychi des Oberjura und der Unterkreide. Paleontographica, A, 88:115-229.

Uhlig, V., 1883. Die Cephalopoden der Wernsdorfer Schichten. Denkschr. K. Akad. Wissensch, Wien. Mathem.-Naturw. Kl., 46:1-290.

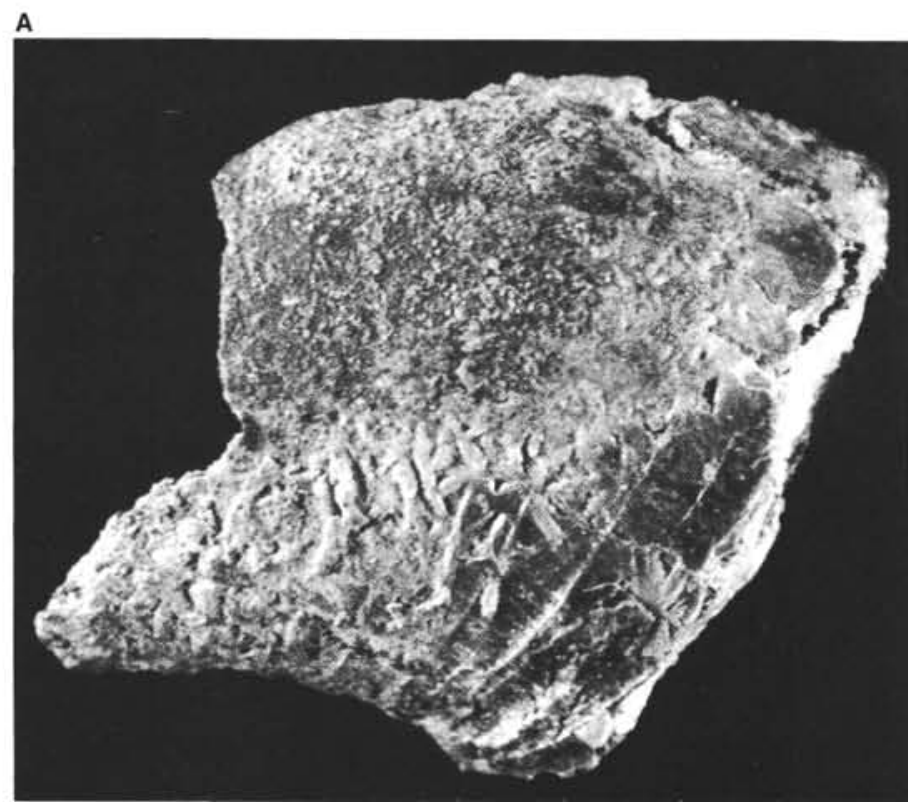

Date of Initial Receipt: 13 February 1985

Date of Acceptance: 5 November 1985

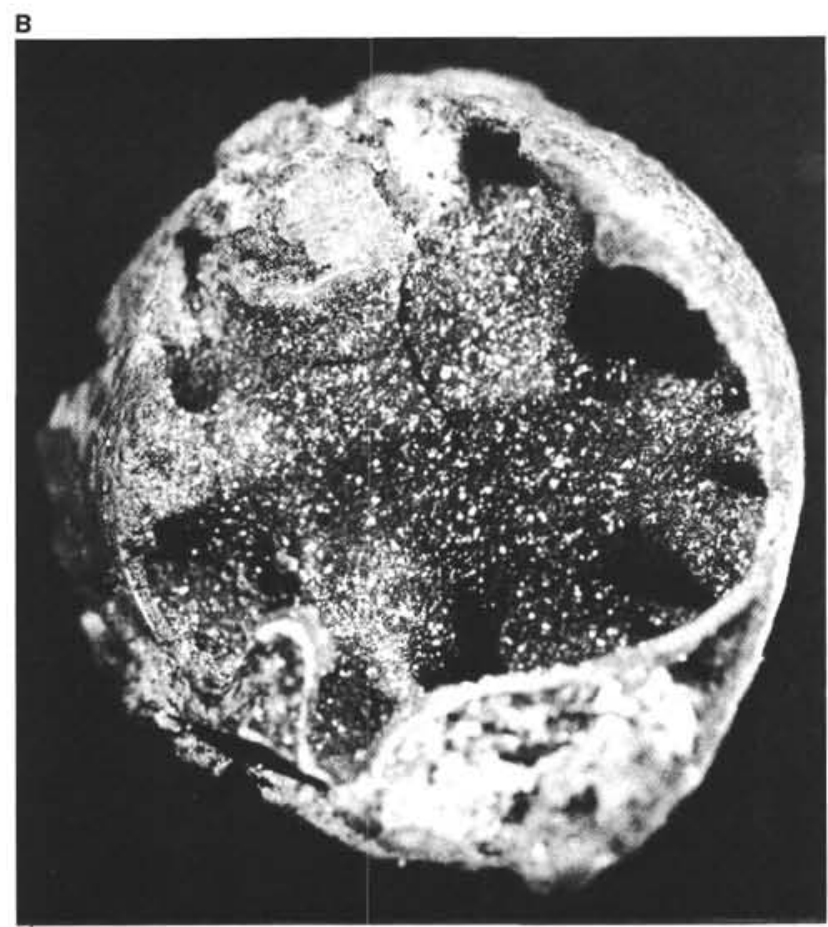

Figure 2. Lytoceras liebigi (Oppel) or L. subsequens Karakasch $(\times 9)$. A. Side view of the whorl fragment showing fine, convex ribs. The delicate, pearly shell is still preserved. Sample 603B-58-3, 140-150 cm. B. Septal view $(\times 9)$ of the same specimen showing the rounded whorl section, the adapical surface of the septum lined with tiny pyrite crystals, large ventral lobe, bifid lateral and umbilical lobes, and a short internal lobe. 


\section{P. J. HOEDEMAEKER}

P. J. HOEDEMAEKER
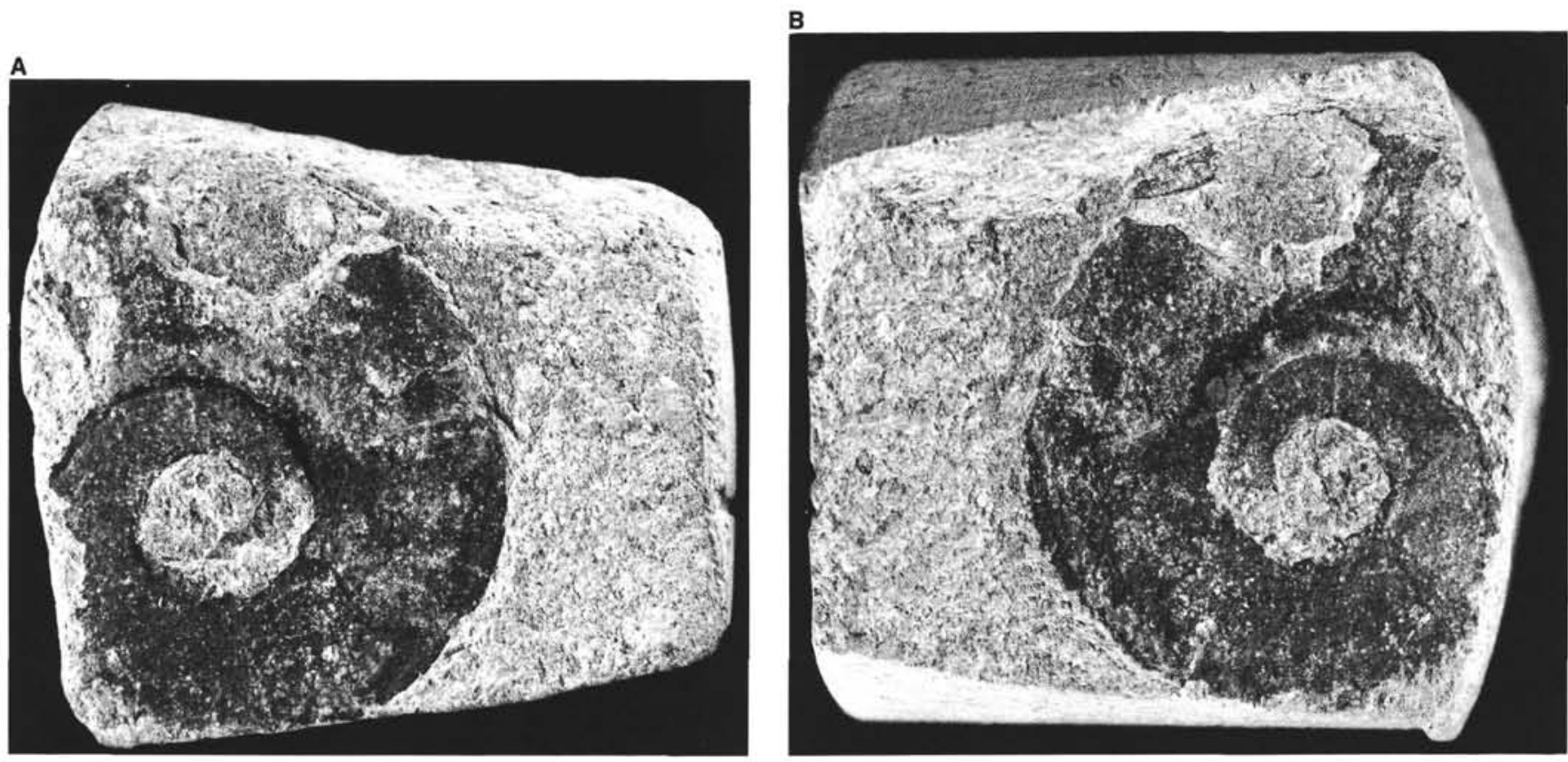

Figure 3. Lytoceras juilleti (d'Orbigny) or L. vogdti Karakasch $(\times 4)$. A. Strongly flattened calcareous mould without any ornamentation or suture lines. Sample 603B-69-5, 11-13 cm. B. Counterpart and impression of the same specimen $(\times 4)$.
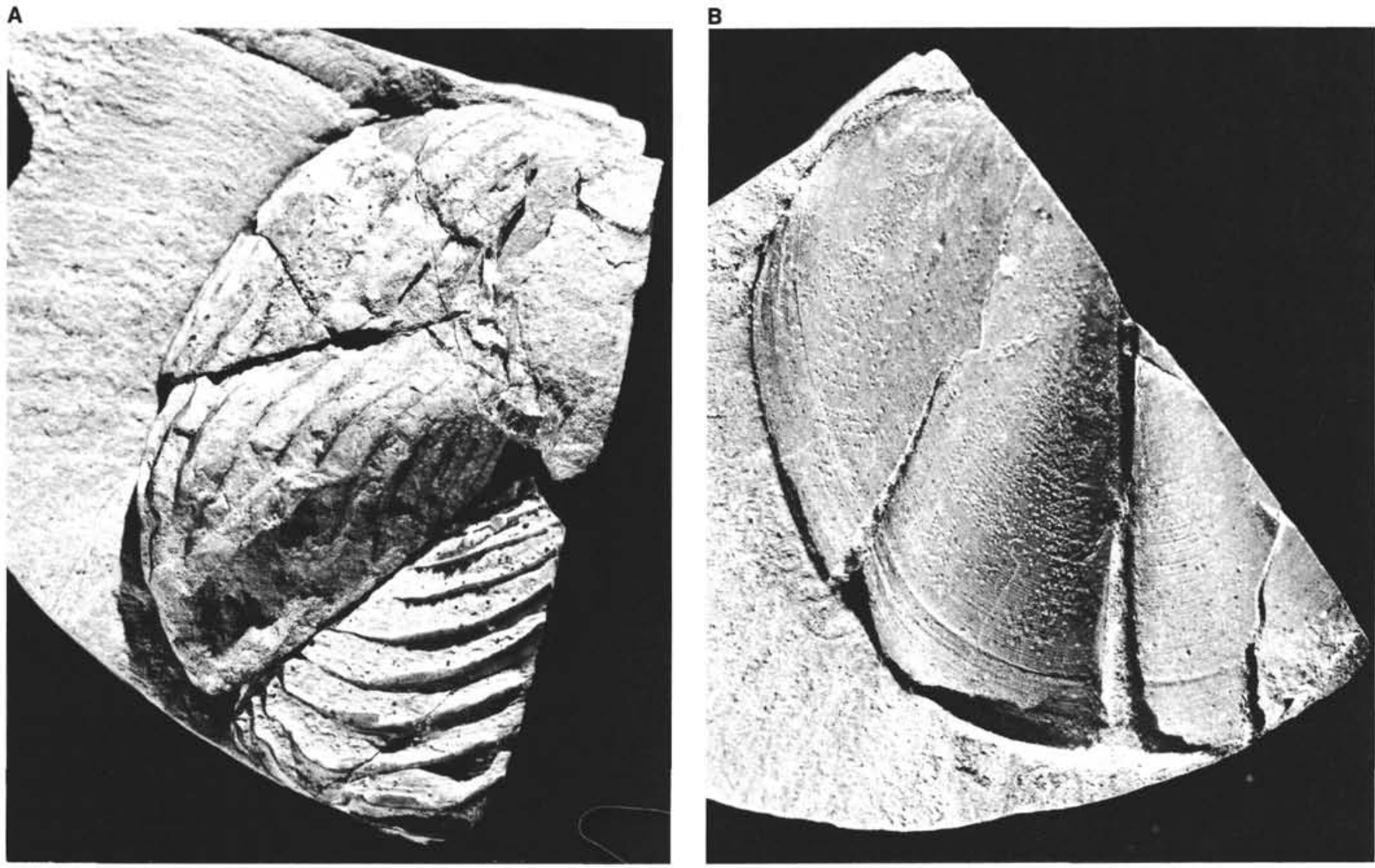

Figure 4. Lamellaptychus beyrichodidayi Trauth $(\times 5)$. A. Outer ribbed sides of the valves. The small fragment of the left valve shows the diagnostic change of the angle at which the ribs reach the symphysal margin. The large fragment of the right valve shows the keel and the inflection of the ribs in the adjacent depression (along the fracture). Sample 603B-79-2, $94 \mathrm{~cm}$. B. Impression $(\times 5)$ of the inner sides of the valves of the same specimen showing the fine, concentric growth lines. 


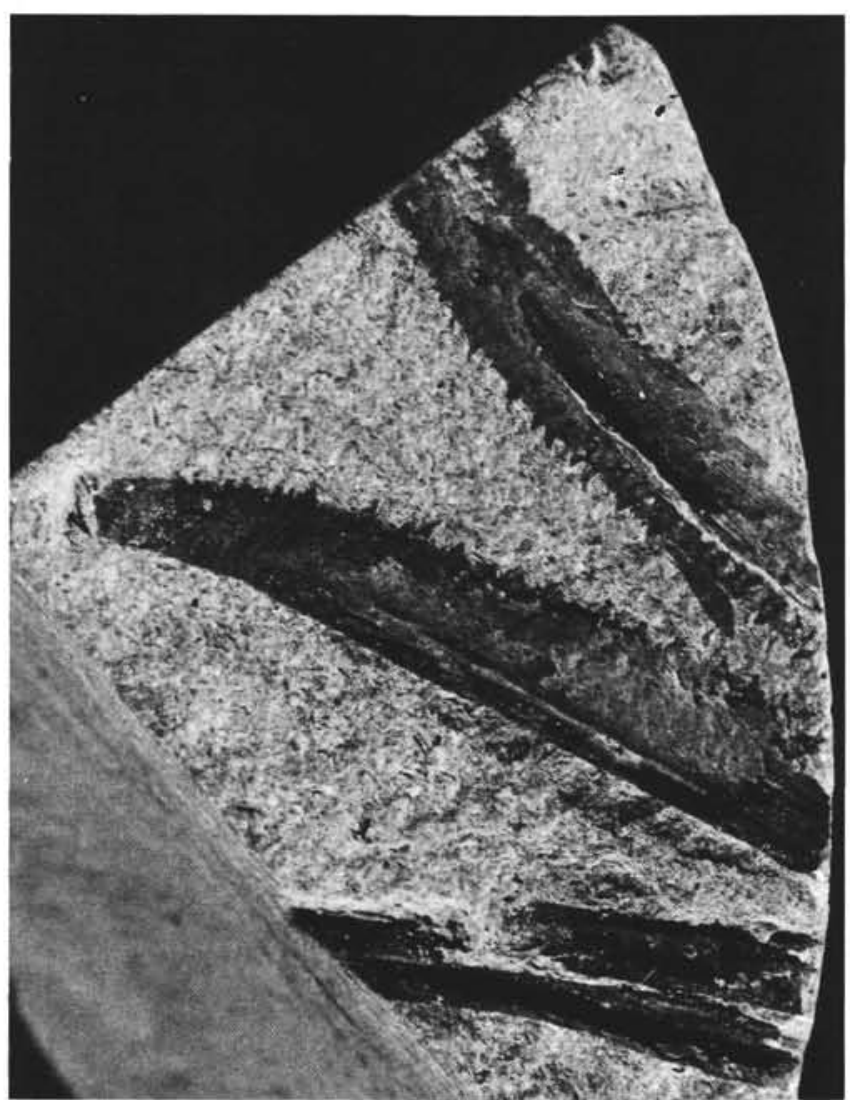

Figure 5. Two slightly curved dentary fragments (lower jaw) of an actinopterygian fish $(\times 8.2)$, and two other bone fragments. Note the small, irregularly sized, cone-shaped teeth which are curved backward. Sample 603B-80-1, 23-24 cm. 